\title{
THE UNIQUE CHINESE INNOVATION PATHWAYS: LESSONS FROM CHINESE SMALL AND MEDIUEM SIZED MANUFACTURING FIRMS
}

International Journal of Production Economics

http://dx.doi.org/10.1016/j.ijpe.2016.09.004

\section{Abstract}

Many researchers equate the development of Chinese product innovation capabilities to Japanese and South Korean's development paths, that is, from imitation to innovation. Nonetheless, today many Chinese products have competed successfully in the global markets in terms of speed, cost, quality, and innovativeness. China's product innovation performance has gained the world's recognition. The performance of some industrial areas have also outperformed Japan and South Korea. This paper aims to understand and identify the unique phases of Chinese innovation. We collected empirical data from field studies and interviews with managers of ten small and medium enterprises (SMEs) in the Suzhou province of China. The research shows three unique Chinese innovation phases that are distinctive from the Japanese and South Korean. The results provided interesting insights into how Chinese SMEs in different industries cultivated their skills and knowledge under the three unique phases. We believe the findings contribute towards a better understanding of Chinese innovation in the context of China's evolving institutions and growing firm capabilities. Moreover, findings from this research help to shed light on existing debates for the unique Chinese innovation pathways.

Keywords: Chinese Innovation, SME, Product Development, Imitation, China, Shanzhai 


\section{INTRODUCTION}

After decades of open door policies, China has become the world's largest manufacturing base and market. Its innovation capabilities have been largely enhanced (Xin et al. 2010; Tan et al. 2015) through decades of learning and cooperatives activities with foreign firms and strategic partners (Chung, 2014; Wang et al. 2016; Yang et al. 2016). However, the "Made in China" label is still generally associated with the characteristics of cheap and poor quality products. The innovation achievement of China is not widely acknowledged and many people still see China as a 'duplicative imitation' country (Cheung, 2011). In order to change this common stereotype and enhance the sustainable competitiveness of Chinese products in the global market, the Chinese government is transforming itself from "Made in China" to "Design in China" by establishing many initiatives to boost innovation capabilities (China State Council, 2015; Huo et al. 2013). In recent decades, certain Chinese industrial products have won a significant share of global revenues, markets and profits. According to McKinsey Global Institute (2015), China performs well in customer-focused and efficiency-driven innovation manufacturing products, in particulary in the areas of customer products like mobile phones, household appliances, solar panals and railway equipments. This suggests that Chinese manufacturing firms have strong innovation capabilities. However, most of the previous studies mainly focus on the large firms and giant state-owned enterprises, without paying much attention to the small and mediurm sized enterprises (SMEs). Indeed, SMEs play a significant role in building up their innovation capabilities within the China's growing manfacturing ecosystems. For example, Shenzhen has a strong ecosystem that includes more than thousands of manufacturers in electrical equipments, apparels, electronics and materials. Most of them are SMEs that enable 
Shenzhen to have a strong competitive edge in terms of speed and costs in developing prototypes, access into a large supplier base, and move products into global markets quickly (McKinsey Global Institute, 2015).

However, building innovation capabilities for sustainable growth is a big challenge for SMEs. Data from the Chinese statistics year book (2011) shows that $60 \%$ of Chinese SMEs had shut down within the first five years, and only $10 \%$ of SMEs still operating after ten years. Such phenomenon demonstrates the common problems face by most Chinese SMEs when come to product innovation; i.e. lack of sufficient technological capabilities and capital support (Radas and Bozic, 2009). Thus, how to boost innovation capabilities have become the primary goal for both Chinese government and SMEs owners.

So far, limited studies have investigated the innovation development phases in China SMEs. Recent studies tend to equate Chinese product innovation development phases as from imitation to innovation (Zhu et al. 2012) or equal it to the early Japanese and Korean development stages (Zhou, 2006). Thus, knowing how to improve product innovation performance is critical for Chinese SMEs in today's' intense competitive market (Kim, 2001). Clearly, Chinese SMEs face two key questions: a) are Chinese innovation phases unique from Japanese and South Korean? and if so, b) what are the needed capabilities and key challenges in each phase?

In order to answer these questions, we collected empirical data from field studies and interviews with managers from ten small and medium enterprises (SMEs) in the Suzhou province of China. The paper is structured as follows. A review of the literature establishing the current state and phases of Chinese SMEs' innovation. The 
methodology section then describes the sample used and the research method. The next section presents the research findings and suggests implications for research and practice. The final section concludes the paper by summarizing the issues, pointing out the limitations, and outlining areas for future research.

\section{SMEs INNOVATION CHALLENGES AND OPPORTUNITIES}

Several scholars have pointed out a number of factors which may adversely contribute to SMEs product innovation capabilities (Guan and Ma, 2003; Alvarez and Iske, 2015; Whittaker et al. 2016). Li and Atuahene-Gima (2001) argued that product innovation can be a high risk and resource consuming activity. In general, the resource constraints that SMEs suffering can be divided into four categories: financial resources, marketing and management, technical capabilities, and human resources availabilities (Kim, 1997; Ragatz et al. 1997; Hadjimanolis, 1999; Freel, 2000).

Freel (2000) argued that the majority of SMEs are directly or indirectly affected by shortages of financial resources. Without sufficient capital support, many SMEs may shrink back, fear of attempting to carry out new product development again if they have a failed experience previously (Hadjimanolis, 1999). Also, Dacin (2010) stated that although many SMEs have a detailed product innovation plan, high setup cost, high monitoring cost and long payback period usually slow down their strides to new product R\&D. This is particularly true for SMEs in China. Siu et al. (2006) pointed out that due to capitalism, practitioners in a socialist nation such as privately-owned SMEs in China were not socially acknowledged in the past. Under such environment, Chinese SMEs had to implement other ownership structures to achieve legitimacy such as joint venture, small individual enterprises and collective enterprise (Malik, 1997). As such 
unclear ownership structures have been continuing to now, Chinese SMEs have to rely on informal channels to obtain loans (Wang and Yao, 2002).

Apart from the influence of capital requirement, poor management competency and lack of market information can also negatively impact SMEs on their new product development capabilities (Ragatz et al. 1997; Zhou, 2006). Management competency, in other words, refers to a manager's background such as relevant career experience and educational background. Barker and Mueller (2002) pointed out that both managers' previous work experience and educational background has a significant impact on corporate new product R\&D decisions. For example, a manager with rich working experience and higher education may be more likely to adopt innovative activities, and vice versa. With respect to marketing management, Moenaert and Souder (1990) stated that firms could be constrained in new product $R \& D$ as they were unable to obtain sufficient information from the marketplace (Chong \& Zhou, 2014).

In addition, poor technological capability also inhibits SMEs' new product development (Zhang \& Dhaliwal, 2009). Prior researches argued that technological capability can be affected by two major factors: absorptive capacity and collaborative network (Kim, 1997; Zahra and George 2002; Zeng et al. 2010; Chen et al., 2016; Yang et al., 2016). SMEs also face difficulties in recruiting qualified technical personnel (Freel, 2000). Ability to recruit key human resource personnel is critical for implementing successful innovation, especially at the beginning of new product development (Dacin, 2010). This deficiency is even more extreme for SMEs in China because they need to compete with foreign firms and large SOEs in hiring experienced managerial and technical staffs. SMEs tend to lose in the recruitment battle as large firms usually can provide 
better compensation packages to attract high competent talents (Dobson and Safarian, 2008).

Lybaert (1998) found that SME firms with higher capability in searching and absorbing external knowledge are more optimistic to adopt product innovation (Chen et al. 2016). Also, in the absence of sufficient highly qualified labour, most SMEs cannot assimilate external knowledge well nor apply it into product innovation. Likewise, SMEs are more likely to rely on interfirm cooperation (Yang et al. 2016) rather than on horizontal collaborations such as cooperation with government, research institutions and intermediary organisations (Zeng, et al. 2010). However, such horizontal collaboration is gradually becoming the key element to successful product innovation (Godin and Gingras, 2000 ). Due to limited resource, Chinese SMEs have to establish links with other firms, such as supplying basic components or services to large firms, and collaborating with other SMEs in order to broaden their technological knowledge base for product innovation (Liefner et al. 2006). According to a recent survey of 3000 small business executives in China, more than 30 percent cited lack of innovation capability as the main barrier to growth (Guangzhou Cooperation Office, 2013). Some scholars further noted that Chinese SMEs tend to imitate or copy others product design in order to overcome the resource and capability limitation and to reduce product development cost (Minagawa, et al. 2007).

Besides resourse and capability limitation, many studies indicated that government intervention was a driven force behind SMEs' product innovation performance in China (Li, 1998; Wang and Yao, 2002; Xie and White, 2006; Huo et al., 2013). Cheung (2011) stated the role of Chinese SMEs has been expanding in the changing socio-political environment. Due to the characteristics of SMEs, such as small firm size and the ability 
of fast response to market trends, SMEs are capable to carry out more efficient new product development than large firms (Tan, 2001). Recently, Chinese SMEs increasingly recognize that they need to enhance their ability to develop new products and differentiate their own brands from competitors (Siu et al., 2006). Furthermore, some researchers point out that several Chinese SMEs have successfully grasped such opportunity and transformed into large enterprises that generate their particular brands (Wang and Yao, 2002). The stories of Huawei, Haier, ZTE epitomise the prowess of successful Chinese SMEs transformation.

\section{PRODUCT INNOVATION DEVELOPMENT PHASES}

Product innovation development phases can be referred as the learning sequence from assimilation and accumulation of knowledge or skills to transforming the technological capability into new products. Some scholars conceptualise this term as the process from imitation to innovation (Choi, 1989; Kim, 1997). With respect of the role of imitation in product innovation, most researchers believe that imitation can bring a positive significant impact. For instance, imitation can be an evolutionary approach (for example, Abernathy and Utterback, 1978; Nelson and Winter, 1982; Dosi, 1982), imitation contributes to a firm's product development (for example, Teece, 1986) and imitation may enhance a firm's competition position on the perspective of inventors' return on profit (for example, Bessen and Maskin, 2009).

However, Aghion et al. (2001) argued that excessive imitations can result in adverse effects on corporate growth. They further noted that imitation has minimum benefits to enhance growth. Therefore, the effects of imitation on company growth is still not fully determined. In order to build innovation capabilities in a step by step approach, most firms tend to imitate their competitors. Many researchers point out that early 
development stages of Japanese and Korean manufacturing industry are incremental in nature; i.e. from imitation to innovation.

Nonetheless, will the Chinese SMEs follow the same product innovation capabilities development paths taken by the Japanese and South Korean? Do Chinese SMEs encounter similar or different kinds of challenges and opportunities in the processes of building up innovation capabilities? The following sections investigate and compare the product innovation development phases in Japan, Korea, and China.

\subsection{Product innovation development phases in Japan}

Interestingly, many researchers argue that the Japanese's learning development can be dated back to $15^{\text {th }}$ century. A sword master named Miyamoto Musashi stated that learning process can be divided into three stages and proposed a concept of Shu-HaRi (守破離) (i.e. “obedience-breakdown-breakaway”) in his book (see figure 1). Till now, the concept of ' Shu-Ha-Ri' has impacted many generations in Japan. The concept has three key stages. In the initial stage, students should learn from the masters and faithfully obey them. Subsequently, once the students are able to master the skills proficiently, they should break away from the 'old' practices gradually. Finally the students would depart from the tradition teachings to establish their own values (Proctor and Tan and Fuse, 2004). 
Figure1: Shu-Ha-Ri (obedience-breakdown-breakaway) Japanese learning sequence

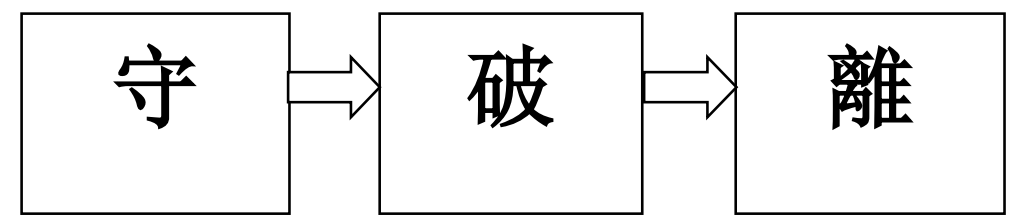

After the Second World War, Japanese manufacturing industry grew at an incredible speed. The growth is strongly supported by the US led Allied Occupation Forces (AOF) (1945-52), a campaign to rebuild the nation began. The Japanese actively learnt new American management theories and practices in order to catch up with the industrialized world, and acquired foreign technology licences, advanced manufacturing machinery and capital goods. 'Statistical quality control methods' and 'quality control implementation' were transferred to Japan respectively by two American industrial scientists in the 1950s-W. Edwards Deming and Joseph M. Juran. Over time, the Japanese progressively applied the notion of quality control to develop a unique management paradigm - a 'company-wide', or 'total quality management approach'- built on the local cultural logic of kaizen (Mizuno, 1988). This can be a classic example of how Japanese adopted the traditional learning process of Shu-HaRi to achieve competititveness through the development of innovative management and manufacturing system.

Many earlier innovation literature pointed out that when a Japanese entrepreneur gained the knowledge from the front lines of technologies and developed a new product; competitors would imitate his product and learn from it (Hirono, 1986; Cross, 1990; Bowonder and Miyake, 1992). However, the learning process is more than just a simple imitation. During the imitation process, Japanese firms will select and master the useful skills independently, while improving and transforming the basic 
technologies into new products. The continuous improvement in products and business prcoesses (i.e. kaizen) were acheived through 'grass-root' company-wide and 'collective' efforts. The implementation of kaizen is best represented by Toyota, the largest automobile manufacturer in the world. Toyota was not a product innovator when it was established in the early 1930s. They used to be a follower of Ford (e.g. imitate the expertise for the electrical systems). However, Toyota subsequently improved the technologies to innovate new products and outperformed Ford eventually (Nonaka and Takeuchi, 1995). The majority of Japanese firms believe that once they have absorbed new knowledge from others, their desire would reach a higher level of innovating them (Imai et al., 1984).

\subsection{Product innovation development stages in South Korea}

There is no doubt that South Korea has become an advanced industrial economy in Asia after the emergence of Japan. The modernization of the country is largely stimulated by the government policy of promoting a selected number of private companies by arranging preferential access to local loans and foreign exchange. They are the representatives of Korean Chaebols. Kim (1997) highlighted that the key success factor of South Korea's fast industrialization can be attributed to the accumulation of technology capability. In the early stage of industrialisation, many firms (i.e. Samsung, Hyundai and LG) engaged in foreign joint ventures (JVs) for learning and securing access to new technologies.

In the case of South Korea's transformation, technology capability can be defined as the ability to effectively absorb, utilize and change external knowledge in order to either improve existing products or create new technologies to meet the fast-changing business environment. Further, Kim (2001) revealed that South Korea's 
industrialisation had undergone three stages, which are duplicative imitation stage, creative imitation stage and innovation stage (see Figure 2).

Kim (2001) also underlined the most critical determinants in duplicative imitation - i.e. South Korean firms build their knowledge-building mechanisms through the way of employees training, foreign technology transfer and the diffusion of new knowledge among all the technical workers across the companies. South Korean companies strived to obtain advanced technologies through formal mechanisms such as technical licensing agreements or informal mechanisms such as literature and technical assistance. In the creative imitation stage, South Korean firms attempted to reach higher level by gradually improving their products values. They do so by cooperating with local universities and research institutions. Moreover, they also fostering local technical talents, carrying out internal technology research \& development, building strategic alliance with foreign companies. Eventually, the South Korean entrepreneurs made major shift from imitating advanced technologies to developing innovation technologies by themselves. In the innovation stage, firms will implement a series of activities to foster corporate innovation; i.e. intense investment in internal $R \& D$, strengthen collaborations with universities and research institution, and hiring highquality experienced technicians from overseas.

Figure 2: South Korean product innovation development stages

\begin{tabular}{|c|} 
Duplicative \\
imitation
\end{tabular}$\Rightarrow \begin{gathered}\text { Creative } \\
\text { imitation }\end{gathered} \Rightarrow \begin{gathered}\text { Innovation } \\
\text { stage }\end{gathered}$

3.3 Chinese firms' catch up: Different product innovation development stages 
It is apparent that both Japan and South Korea have achieved industrialisation gradually through innovation stages discussed above. Many Chinese entrepreneurs may ask: "should we emulate the imitation to innovation paths taken by Japanese and South Korean firms?" In 2006, Chinese government proposed the "11 th Five-Year Program" plan to promote technological capability across the country in order to maintain a sustainable growth in the future (Government of People's Republic of China, 2006). Since then, Chinese firms are encouraged to make transition from labourintensive manufacturing to more mature technology-intensive industries (Xie and White, 2006). Subsequently, a large number of Chinese firms have improved their technology diffusion and knowledge transfer by recruiting foreign talented technologists, establishing strategic alliances with overseas firms, and purchasing technical patent licensing from abroad (Fan, 2014).

As Japanese and South Korean firms' product innovation emerged after the WWII, as such several innovative determinants such as education, financial resources, technology, collaborations with foreigners were at a very low level (Kim, 1997; Herbig and Jacobs, 1997). In contrast, the economy of China is growing at the rate of around 8-9 percent annually in the past three decades (WTO, 2011). Thus, Chinese firms have more resources to support product innovation; i.e. larger pool of qualified personnel, sufficient raw materials, and good collaborative relationships with foreign organisations (Xie and White, 2006). Hence, based on such a strong economic and political environment, Chinese firms may have their own unique product innovation trajectory compared to Japan and South Korea (Dobson and Safarian, 2008). Kim (2001) stated that during the stage of duplicative imitation, most South Korean firms can only rely on science and technology knowledge from abroad. In contrast, with the advancement of internet technology and other transportation and communication means, Chinese firms are able to access the latest scientific technologies from thousands of universities and 
research organisations (Zeng et al., 2010). Thus, even in the early stage of product innovation, Chinese firms are able to obtain sufficient knowledge to support new product development.

Thus, with better resources and knowledge, the "imitation" phase for Chinese firms can be more than just simple "Duplicative imitation" or "obedience". Dobson and Safarian (2008) argued that Chinese firms executes imitation strategy with larger aims i.e. a) to reduce product innovation failure risks; and b) to accumulate enough knowledge and funds in order to carry out product innovation more efficiency in the future.

Thus, we can identify the phenomenon of the unique Chinese innovation pathways: 引 (Yin)-调(Tiao)-创(Chuang) in Chinese (see Figure 3). The initial product innovation development stage for Chinese firms can be named as “引(Yin)". The term "Yin" in Chinese has the meaning of introducing and adopting others' knowledge or experience to achieve a better result. Likewise, the next product innovation development phases can be described with another Chinese word; i.e. “调(Tiao)". It means a way to adjust and improve the existing products. From the viewpoint of Chinese firms, this step is seen as a transition stage between imitation and innovation. According to Xie and White (2006), Chinese firms usually like to test the market reaction by adding a number of new features on the existing products. Hence, Chinese firms at the Tiao phase is closer to innovating new products than the stages of "creative imitation" and "breakdown" in South Korea and Japan respectively. With respect to the innovation stage, it is defined as “创(Chuang)" in Chinese word, which denotes the meaning of altering the original designs and creating new products for more profit. However, only a small number of Chinese firms, in particularly the SMEs, can develop new products due to resource limitations and other barriers we have mentioned before. 
Figure 3: The three Chinese firms product innovation development stages

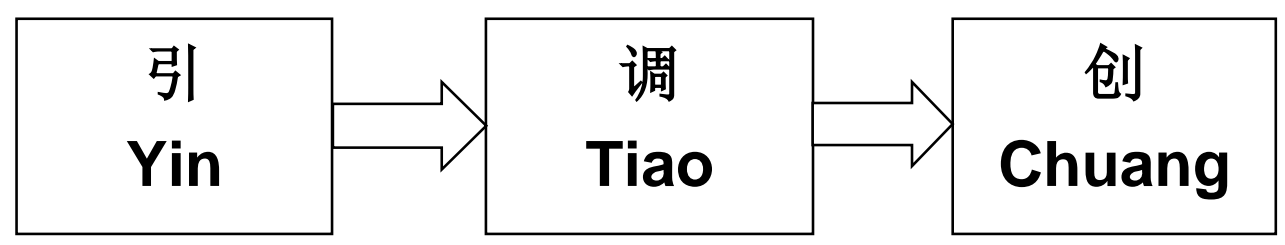

\section{RESEARCH METHODOLOGY}

\subsection{Data Collection}

After examining and comparing the 3-phases of product innovation development in Japan, South Korea and China, a series of fieldwork and semi-structured interviews (Yin, 2003) were conducted by the researchers to further explore the validity of the proposed Chinese innovation phases in practices. Ten SMEs from the Suzhou province of China were selected for case study. All these 10 companies were keen to support our research because: a) the timing was good - these companies were keen on developing new products and were willing to understand if their approaches were effective or not; b) these companies had been searching for potential product ideas and markets, and were interested to understand current innovation approaches; and c) these companies had their own version of innovation approach, and wanted to tap into new ideas to enhance their current practices.

Suzhou province was targeted because it is a location with a unique innovation system where SME innovation contributes a much higher share of regional sales than the large firms do (Liefner \& Wei, 2013: p.61). When building theory from case studies, researchers normally select cases using replication rather than sampling logic (Voss et al., 2002). Thus, it is vital to select cases that provide the best opportunities to learn and extend theory. To increase validity, SMEs from different industries and technology 
levels were interviewed including telecomunication, medical equipment, electronic, textile, fabricated metal products, and furniture (see Table 1).

Table 1 shows a brief background of the case companies.

\begin{tabular}{|c|c|c|c|}
\hline Case & Main products & Position of the key Interviewee & $\begin{array}{c}\text { Average } \\
\text { working year }\end{array}$ \\
\hline A & Clothes and textiles & CEO, R\&D manager & 6 \\
\hline B & Electronic chips & $\begin{array}{c}\text { General Manager, R\&D Manager, } \\
\text { Project Manager }\end{array}$ & 11 \\
\hline C & Silk products & CEO, General Manager & 3 \\
\hline D & Scarf and clothes & CEO, Project Manager & 7 \\
\hline E & Metal products & CEO, General Manager & 10 \\
\hline F & Cell phones & General Manager, Project Manager & 4 \\
\hline G & Furniture & General Manager, Project Manager & 5 \\
\hline H & $\begin{array}{c}\text { Computer } \\
\text { components }\end{array}$ & CEO, R\&D Manager & 3 \\
\hline I & Medical equipment & CEO, General Manager & 5 \\
\hline J & Plastic products & General Manager, Project Manager & 5 \\
\hline
\end{tabular}

Face-to-face interviews were conducted with owners and multi-level managers (i.e. CEO, General Manager, R\&D manager, and Project Manager) as well as with a selection of new product development (NPD) team members. We also collected data from field observations and documentations. The study is primarily exploratory. The aim of data analysis is to develop a theoretical framework as the story unfolded and to provide insights for further theoretical articulation. This approach is particularly useful for this study context because it can help to document the innovation management phenomenon within its organizational context, identifying the boundaries, and integrating data from various sources.

The interviews were conducted in Mandarin. The interviews lasted between one and 
two hours, they were recorded and transcribed. Field notes were also taken as a backup in the event of equipment failure. Respondents were asked questions on the key phrases of innovation management and identification of key capabilities and challenges on each phrase. The aim of the interviews was to understand the scope, extent, causes, environmental and organizational factors (both internal and external) that underlying the processes of the innovation management in the studied firms. Upto-date written materials and reports about their operations were collected directly from managers after finishing the interviews. Interviewees were chosen for the managers' knowledge and experience of innovation management. All of the formal interviews were conducted in the offices of the interviewees. Some of the informal interviews also took place with managers and other R\& D staff when the interviewers were conducting field observations. Hence, the data are drawn from multiple levels and various perspectives. The extent of the fieldwork, the number of interviews, and the quality of the data provides important insights for the present study.

\subsection{Data Analysis}

Each interview was recorded and written up as an interview report in Microsoft word files, including the interview's content and the author's on-site observations. All the qualitative data were underwent systematic data analysis stages (Locke, 2001). Three main stages of data analysis were carried out; i.e. data reduction, focused coding, and data display.

The data was analyzed using inductive techniques. The transcribed codes were arranged by case, interview number and type of questions. After numerous iterations, a system of well-defined codes (e.g. common themes, concepts, categories, and insights) was developed. They are then systematically interrelated through statements 
of relationship and used to build up a theoretical framework that explains the relevant studied phenomena. Once concepts are developed through statements of relationship and build up into an explanatory theoretical framework, the research findings move beyond concept organization to theory generation.

The inter-relationships of codes were identified through both within-case and crosscase analyses. These two types of analysis are driven by the logic of the 'constant comparative method' rather than sampling logic (Eisenhardt 1989; Yin 2003), and aimed to critique and extend existing theory. Relationships and categorizations are tentatively proposed when working with the data, and then verified inductively, by comparing similar incidents in different cases. This interplay between proposing and checking augments helps to enhance the construct validity of the theory generated (Eisenhardt, 1989; Strauss \& Corbin, 1998).

By investigating the examples of innovation management, the three dominant themes were identified: "Yin, Tiao, and Chuang". The next stage was to explain the main themes with their conceptual properties and dimensions. The final stage was to generate the relationship among the themes and categories and further explain the innovation phrases and the key factors affecting them.

In order to ensure the accuracy of the codings, the author invited an independent reviewer, blind to the purpose of the research, give some representative examples from the data of each category, and instruct to code some randomly chosen data. In addition, the findings were discussed to double check for the reliability of codings and meanings of the data. There is over $90 \%$ of agreement in the coding samples. The analyses were based on the triangulation of data sources through archival documents and observation of the interviewed managers and other employees' behaviour. In particular: how people perceived the challenges affecting the innovation management 
they are performing, and how firms adapt their strategies in responses to environmental changes, organizational demand, performance paradigm, and resources and capability buildings. This analytical approach helped to build theory and strengthen the reliability and validity of the findings (Eisenhardt 1989). The findings below illustrate the various phrases of innovation management developed by SMES and the interplay between environment, guanxi building and capability building.

\section{FINDINGS AND DISCUSSION}

Most of the SMEs in the case study do not have a set of product innovation strategy. Managers from cases $\mathrm{A}, \mathrm{F}, \mathrm{H}$ explained the reasons as: a) they do not have extra production capacity as it has been fully used by the original equipment manufacturer (OEM) purchasers; b) process innovation seems to be more appropriate for their development; and c) they would not like to spend too much resources on product innovation because there is no demand for new product in the particular marketplace. Some of comments from the respondents are highlighted in the followings:

"For example, over the past three years, with the recovery from the global financial crisis, more and more foreign OEM purchasers have placed orders to us so that our production capacity has been fully used by them and we do not have any spare resources to develop our new products."

"We believe new product development is essential for us in the future. However, based on the current environment, our primary objectives is to improve the product quality and save cost. In order to survive in the competitive market, exploring new markets may be more difficult than reducing production cost." 
"We do not think new products can contribute to the sales growth and profit growth, so we just produce generic products."

This findings echo to the report of McKinsey Global Institute (2015) - Chinese firms are very good at eficiency-driven innovation. Chinese SMEs put their priorities to enhance efficiency in order to provide low cost products (occasionally with new added features) to the markets quickly. This approach helps to reduce investment risks and provides compettive edges in both domestic and global markets. These practices are the characteristic of the 'Yin' phases. Under this phase, Chinese SMEs mainly absorb and learn new product knowledge through cooperation with OEM and foreign firms.

SMEs owners from high-tech manufacturing industries have different perspectives on product innovation. In contrast to low-tech industries, most of the high-tech manufacturing SMEs have developed innovative products on their owns; i.e. in the 'Tiao' phase. Manager in Case B pointed out that one of the reasons for this is because high-tech manufacturing SMEs tend to build collaborative relationships with research institutions. However, some of the managers also revealed that the research focus of some higher education institutions are usually not consistent with the market trend. They also pointed out that cooperating with customers is more valuable than cooperation with government agencies. Two SMEs entrepreneurs from Electronics industry and Medical Devices Manufacturing industry said:

"Since we signed the contract with universities, the features they designed cannot be applied into our products at all. In fact, our initial objective is to hope that they can provide us with new technology support, but their target is to make contributions to academic circles. This cannot always match our needs. In addition, research 
institutions spend too much time on new product development, as a result, we have missed the best timing for considerable commercial opportunities."

"The role of government tends to be less important than the beginning of Chinese economic reforms. At the beginning, relevant government agencies came over our plant and told us how to improve existing products and to design new products. However, China now is transforming to be a socialist market economy and all of the Chinese privately-owned enterprises can only rely on themselves to develop new product. Instead, we increased the frequencies to communicate with customers, because their valuable feedback is significant for our product innovation.

The above findings also highlight the importance of customer feedbacks in the product innovation processes for SMEs. Due to the large and dynamic market, Chinese firms have been proved to gain a competitive edge in customer-focused innovation (Mckinsey Global Institute 2015). The findings also suggest that SMEs tend to reply on customers' opinions for product innovation than on the research findings from research institutions and government agencies. This also explains partly why science-based innovation is still not widely received as fruitful approach for Chinese firms innovation. Nevertheless, it has been evident that SMEs have a strong desire to innovate. However, most of them still found that customer-based innovation is a more feasible approach than the scientific research based ones.

On the top of highlilghting the common challenges and opportunities for SMEs to develop innovative products and manufacturing processes, the interviewees in Case $B$ also describe the way how product innovation is carried out. 
"Before product innovation activities are conducted, we first analyze the future market trend and search the product gap. We attempt to tap into the gap among the existing product and analyze the commercial value in the future. Then, we will generate ideas how to design the new product, pre-determining the initial features about the new product. A market survey will be subsequently undertaken to realize the expectation from market place. During this process, we ask the questions about the number of manufacturers in this field and the source of the raw material. We will analyze the results from the survey and determine whether we should implement the product innovation plan or not. If this plan is feasible, we will make a small number of samples to test the market reaction. Meanwhile, we will change some features according to the feedback from consumers. Until everything is perfect, we will launch the new products in large scale."

In general, the formal sequences of new product development in most Chinese manufacturing SMEs were identified from the interviews: 1. Existing product gap search, 2. Idea generation, 3. Market survey and analysis, 4. Sample development, 5. Sample test in small range, 6. Market reaction analysis, 7. Sample modification, and 8. Mass production. These steps suggest that some SMEs are following a systematic and scientific process to develop new products, these SMEs have already entered the 'Chuan' stage.

However, the role of immitation in the innovation processes can be still very prominent in some industries. For example, some managers commented that some small firms create new products by adopting an informal approach. Interestingly, in China, such new products are called "Shanzhai" Products. The term "Shanzhai" refers to the definition of pirating the ideas, brands and product appearances from other famous 
brands in order to forge the similar products with a lower price and a poor quality. One industrialist from Electronic industry explained the way how the 'Shanzhai' works :

"Those 'shanzhai' firms do not need to do product innovation because only copycat approach is enough. All they have to do is just to copy other products of famous brands. For example, once new iphone launched, they will buy one from market and analyze the basic features. Then, they just need to make a similar phone with basic 'iphone' features and same product appearance. Indeed, they proficiently master consumer psychology and sell such "Shanzhai" products with a much cheaper price compared with the real iphone."

On the top of identifying the key stages of innovation processes, the interviewees also identified another key factor that affects the SMEs innovation capabilities. They mentioned the phenomenon of "Guanxi", a Chinese term means good connections with other individuals or organisations. During the interview meetings with all the ten SMEs owners, they mentioned "Guanxi" and trust is vital to product innovation performance. In specific, Chinese SMEs with strong "Guanxi" and trust relationship tend to have a high growth of sales and high growth of profit (Wang et al. 2011). Further, especially during the period of new product development, "Guanxi" and networking significantly impact SMEs on new knowledge acquisition (Chong \& Zhou, 2014) and capital funds obtaining. One of the interviewees said:

"We have built good "Guanxi" with other organisations such as bank, government agencies and research institutions. Thus, once my company encounters problems in new product development, we will search relevant Guanxi to address it." 
This phenomenon may relate to the specific Chinese context for innovation. China's manufacturing ecosystem includes many interacting parties who participate in operating transportation and supplying various materials and components that can facilitate speed delivery and production (Mckinsey Global Institute 2015). This complicated network can be greatly enhanced through 'Guanxi' within the ecosystem. Such Guanxi network tends to have impacts on the whole innovation processes (Chong \& Zhou, 2014; Wang et al. 2011).

\subsection{The 3 Phases of Chinese Innovation}

Based on the discussion with the interviewees and data obtained from the cases, this paper proposed a Yin-Tiao-Chuang matrix in relation to SMEs Guanxi network and absorptive capacity (Figure 4). The matrix has two dimensions: Guanxi network and absorptive capacity. The basic idea behind it is that the higher the absorptive capacity a SMEs has or the stronger the guanxi network, the better it is for the company. This helps SMEs allocate resources and identify possible roadmaps for navigating themselves from Yin to Chuang phase.

SMEs at the Yin phase are not able to gain ample new knowledge from other parties, or to transform and absorb external knowledge into new product development. This is because SMEs at the Yin phase tend to have low absorptive capacity (Zahra and George, 2002) and poor collaborative network (Zeng et al. 2010) with others. Thus, they will simply imitate the existing products. 


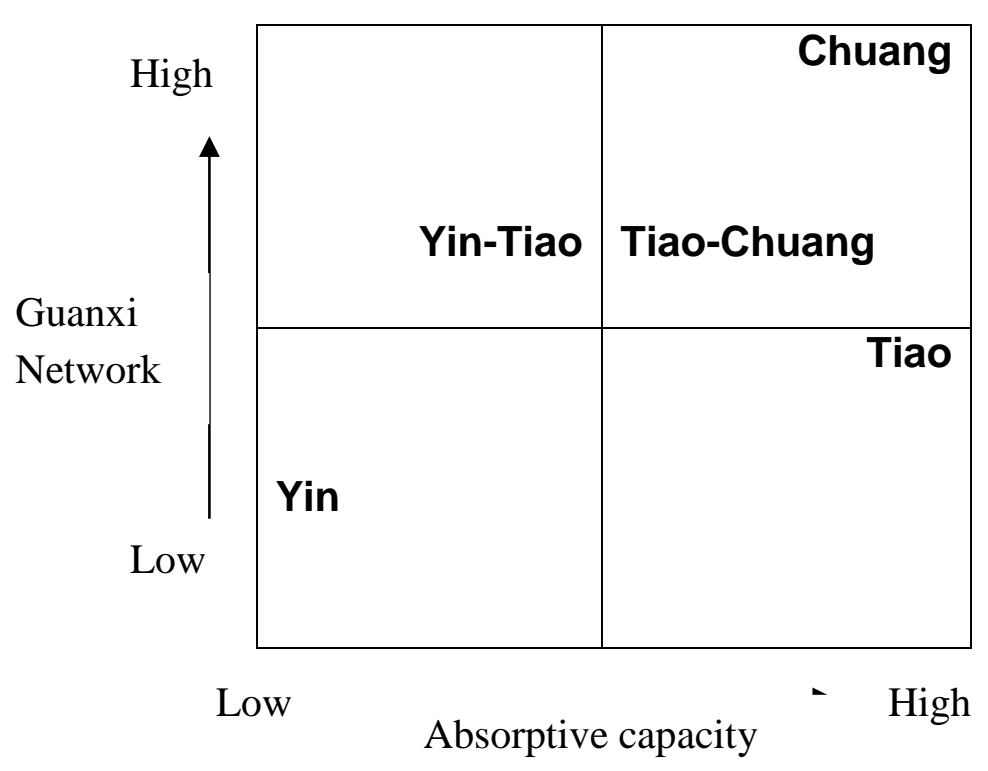

Figure 4. Yin-Tiao-Chuang Matrix in Relation to Guanxi Network and Absorptive Capacity.

The phase between Yin and Tiao can be seen as a transition stage; i.e. SMEs conducting new product innovation through minor changes of existing products features. At the Yin and Tiao stage, SMEs still has low capability to transform and apply the absorbed knowledge into their product R\&D. Nevertheless, SMEs at this phase still cooperate with network collaborators (Yang et al. 2016). Compared to Yin, those at the Tiao phase tend to have a comparatively high absorptive capacity to absorb and analyze the external knowledge, and well transform and apply it into new product development(Xin et al. 2010). As a result, SMEs at the Tiao phase usually can improve some main functions of existing products by themselves. However, Chinese SMEs at the stage of Tiao generally has a medium level of collaborative network. Thereby, their product innovation is often constrained by insufficient technical support (Zhang \& Dhaliwal, 2009). Moreover, without a strong network and distribution chanel, it is an uphill task for SMEs to market their products widely. SMEs at the Tiao-Chuang phase have a higher capabilities of knowledge acquisition, assimilation, transformation and exploitation than the early phrase. Also, they tend to have a strong collaborative 
network to easily access the desired knowledge from external partners for enhancing product innovation activities (Chen et al. 2016). Hence, they can develop a number of new features on the existing products as well as developing unique new products by themselves (Tan et al. 2015). SMEs at Chuang phase can confidently design and develop new products by building good relationships with customers, suppliers, competitors, research institutions, universities, government departments, venture capitalists in order to gain high valuable resources and information (Chong \& Zhou, 2014; Wang et al., 2016; Yang et al., 2016; Zhang et al., 2016).

\section{CONCLUSION AND MANAGERIAL IMPLICATIONS}

In order to have a better understanding of Chinese SMEs' product innovation development stages, this research compared the literature findings of Japan and South Korea product innovation stages. As a result, a unique three product innovation development pathway (Yin-Tiao-Chuang) was proposed to explicitly demonstrate the Chinese SMEs' product innovation development, which has been identified to be quite different from those found in Japan and Korea. The first stage Yin refers to the initial product innovation development stages, i.e. mainly on applying existing knowledge and technology to produce product. It is similar to the imitation stage of Japan and South Korea, except that the Chinese SMEs have to rely on local knowledge and technologies given the limit of direct resources or formal support from western countries. In contrast, Japan and South Korea received a lot of support i.e. technology, access to market etc. under the American administration after the war. Tiao refers to the second product innovation development stage i.e. to adapt the new knowledge and skills gained to improvise new innovation. This is slightly different from creative imitation stage (as in South Korea) because Chinese SMEs have the advantage of vast local market. Thus, SMEs develop new products based on existing skills and 
technologies (learned in the Yin stage) to meet local demands. This is different from the Japan/South Korea where SMEs at this stage will make slight modification of existing products (such as reducing the number features of the original designed products) to offer cheaper alternatives to consumers. This is generally a kind of glocalization strategy widely adopted by the multinational companies (Immelt et al. 2009). The final Chuang refers to the stage of innovating new products. Some Chinese SMEs have achieved this stage and most of them are now becoming multinational firms. For example, Huawei and Haier are examples of Chinese multinational firms, that were SMEs originally and have been transcended to the Chuang stage, making use of the vast knowledge gained from making local products to introduce 'universal' products that can be sold in international markets.

To conclude, most previous scholars simply define the product innovation development stages in China as the transition from imitation to innovation, similar to the catch-up processes achieved by Japan and South Korea. Many Chinese SMEs are suffering from many constraints such as limited advanced technological capabilities, insufficient fund and lack of high qualified workers, which may slow down their progress of product innovation development. Consequently, most innovative SMEs are staying at the transition stage between Yin and Tiao, i.e. begins with more imitation and follows with some incremental innovation, mainly by improving a number of features on the existing products that fit the local market demands. In addition, they usually achieve product improvement through customer feedbacks rather than the results from scientific research. Efficiency-driven innovation is also more emphasized amongst SMEs in order to keep low cost, ensure product quality, and shorten the time for entering the markets. Overall, this research finds many SMEs are at the transition stages i.e. between "Yin" to "Tiao", in particularly among the low-tech and 'shanzhai' 
manufacturers, while the stage between "Tiao" to "Chuang" can also be found in some high-tech sector. All the three stages can greatly enhanced through 'Guanxi' network and trust in particularly supporting within the manufacturing ecosystems, as illustrated in the proposed matrix in Figure 4.

This research contributes to the existing SMEs and innovation bodies of literature. For SMEs literature, this research identified an interesting unique three product innovation development phases for the Chinese SMEs. As the research focusing on the Chinese SMEs, the findings may not be generalisable to SMEs all over the world. However, the three unique phases could be applicable to Far East SMEs manufacturing firms such as those in Taiwan and Vietnam. The Chinese model of innovation can have a global impact and benefits to both developed and developing countries (McKinsey Global Institute, 2015).

\subsection{Research limitations and suggestions for future research}

There are several limitations in this research. Firstly, the research only targeted SMEs in Suzhou province of China. Hence, some bias may exist due to a small sample size. It is suggested for future research to collect a larger sample size from other province or cities in China or in other countries. In the case interview, although we interviewed multiple respondents but they are from the same firm. Thus, such approach may also result in biases or group think. Future research is suggested to use multiple respondents (across the SME supply chain, i.e. suppliers, customers) approach to offset the single information concerns. Moreover, this research did not investigate the relationships between product innovation development phases and absorptive capacity (and network) in more depth. Further research could be conducted to investigate the extent of absorptive capacity on the three product innovation phases, 
especially taken into account of control variables such as managerial characteristics and industry nature.

\section{ACKNOWLEDGEMENT}

This paper was developed with inputs from Mr. Jun Hua, who assisted the case studies as part of his Master degree study.

\section{REFERENCE}

1. Aghion, $P$, Harris $C$, Howitt $P$, Vickers J., 2001. Competition, imitation and growth with step-by-step innovation. Review of Economic Studies. 68(3): pp.467-492.

2. Alvarez, H., \& Iske, P. 2015. Internal Capabilities and External Knowledge Sourcing for Product Innovation in LMT SMEs. Journal of Innovation Management, 3(2), 55-70.

3. Barker, V. L., \& Mueller, G. C., 2002. CEO characteristics and firm R\&D spending. Management Science, 48 (6): pp. 782-801.

4. Bessen, J. \& Maskin, E., 2009. Sequential innovation, patents, and imitation. The RAND Journal of Economics, 40: pp. 611-635.

5. Bowonder, B. \& Miyake, T., 1992. A model of corporate innovation management: some recent high tech innovations in Japan, $R \& D$ Management, Vol. 2 No. 4, pp. 319-336.

6. Cheung, Tai Ming. 2011 "The Chinese defense economy's long march from imitation to innovation." The Journal of Strategic Studies 34.3: 325-354.

7. Chen, K-H., Wang, C-H., Huang, S-Z., Shen, G. C. 2016. Service innovation and new product performance: The influence of market-linking capabilities and market turbulence. International Journal of Production Economics. 172: pp. 54-64. 
8. China State Council, 2015. Made in China 2025. White Paper. Accessed at http://english.gov.cn/policies/latest releases/2015/05/19/content 2814751107035 34.htm on 1 July 2015.

9. Chinese statistics year book, 2011. National Bureau of Statistics of China. Accessed at http://www.stats.gov.cn/tjsj/ndsj/2011/indexeh.htm on 1 May 2015.

10.Choi, H.S., 1989. Transition from imitation to creation, Technological Forecasting and Social Change, 36: pp. 209-215.

11.Chong, A. Y-L., \& Zhou, L. 2014. Demand chain management: Relationships between external antecedents, web-based integration and service innovation performance. International Journal of Production Economics. 154: pp. 48-58.

12. Chung, Leanne 2014. Headquarters' managerial intentionality and reverse transfer of practices. Management International Review 54 (2) , pp. 225-252.

13. Cross, M., 1990. Innovation or imitation: the state of Japanese research, Japan Update, Summer, pp. 19-21.

14.Dobson, W. \& Safarian, A. E., 2008. Making the transition from imitation to innovation: an enquiry into china's evolving institutions and firm capabilities, Working Papers Series 11, Rotman Institute for International Business

15.Dosi, G., 1982. Technological paradigms and technological trajectories: A suggested interpretation of the determinants and directions of technical change. Research Policy, 11 (3): pp. 147-162.

16. Eisenhardt, K. M. 1989. Building theories from case study research. Academy of Management Review, 14, 532-550.

17. Fan, P. 2014. Innovation in China. Journal of Economic Surveys. 28 (4):pp.725745.

Freel, M. S., 2000. Barriers to product innovation in small manufacturing firms, International Small Business Journal, 18: pp. 60-80. 
18.Guan, Jiang, and Ning Ma. (2003) "Innovative capability and export performance of Chinese firms." Technovation 23.9: 737-747.

19. Guangzhou Cooperation Office. 2013. Survey reveals SME activity facing significant challenges.

20. Godin, B., Gingras, Y., 2000. The place of universities in the knowledge production. Research Policy 29 (2), 273-275.

21. Hadjimanolis, A., 1999. Barriers to innovation for SMEs in a small less developed country (Cyprus), Technovation, 19: pp. 561-570.

22. Herbig, P. \& Jacobs, L., 1997. A historical perspective of Japanese innovation. Management Decision, 35 (10): 760 - 778.

23. Hirono, R., 1986. Japanese experiences in technology transfer, Management Japan, 19 (1): Spring, pp. 9-19.

24.Huo, B., Han, Z., Zhao, X., Zhou, H., Wood, C. H., \& Zhai, X. 2013. The impact of institutional pressures on supplier integration and financial performance: Evidence from China.International Journal of Production Economics. 146 (1): pp. 82-94.

25. Imai, K., Nonaka, I., \& Takeuchi, H. .1984. Managing the new product development process: how Japanese companies learn and unlearn. Division of Research, Harvard Business School.

26. Immelt, J. R., Govindarajan, V \& Trimble, C. 2009. How GE is disrupting itself? Harvard Business Review, 87, 10, pp.56-65.

27. Kim, L., 1997. From imitation to innovation: dynamics of Korea's technological learning, Cambridge, MA: Harvard Business School Press.

28. Kim, L., 2001. The dynamics of technological learning in industrialisation, International Social Science Journal, 53 (168): pp. 297-308. 
29.Li, H. Y. \& Atuagene-Gima, K., 2001. Product innovation strategy and the performance of new technology ventures in China, Academy of Management Journal, 44 (6): pp. 1123-1134.

30.Liefner, I., Hennemann, S., Xin, L., 2006. Cooperation in the innovation process in developing countries: empirical evidence from Zhongguancun, Beijing. Environment and Planning A 38 (1): pp. 111-130.

31.Liefner, I., \& Wei, Y.D. 2013. Innovation and Regional Development in China. Routledge

32. Locke, K. 2001. Grounded theory in management research. London: Sage.

33. Lybaert, N., 1998. The information use in a SME: Its importance and some elements of influence. Small Business Economics, 10 (2): 171-191.

34. Malik, R., 1997. Chinese entrepreneurs in the economic development of China. Greenwood Publishing Group.

35. Mckinsey Global Institute. 2015. The China Effect on Global Innovation, October. McKinsey \& Company. Accessed at http://www.mckinseychina.com/wpcontent/uploads/2015/07/mckinsey-china-effect-on-global-innovation2015.pdf?bd0bde on 15 January 2016.

36. Minagawa, Tetsuya, Paul Trott, and Andreas Hoecht. (2007) "Counterfeit, imitation, reverse engineering and learning: reflections from Chinese manufacturing firms." R\&D Management 37.5: 455-467.

37. Moenaert, R. K. and Souder, W. E., 1990. An information transfer model for integrating marketing and R\&D personnel in new product development projects, Journal of Product Innovation Management, 7: pp.91-107.

38. Nelson, R. R. and Winter, S. G.,1982. An evolutionary theory of economic change. Belknap Press Series, Harvard University Press. USA. 
39.Nonaka, I. \& Takeuchi, H., 1995. The Knowledge-Creating Company: How Japanese Companies Create the Dynamics of Innovation, Oxford University Press, UK.

40.Proctor, T. Tan, K. H., Fuse, K., 2004. Cracking the incremental paradigm of Japanese creativity, Creativity and Innovation Management, 13 (4): pp. 207-215.

41. Radas, S. \& Bozic, L., 2009. The antecedents of SME innovativeness in an emerging transition economy. Technovation, 29: 438-450.

42. Ragatz, G. L., Handfield, R. B. and Scannell, T. V., 1997. Success factors for integrating suppliers into new product development. Journal of Product Innovation Management, 14: pp. 190-202.

43.Siu, W. S., Lin, T. L., Fang, W. C., Liu, Z. C., 2006, An institutional analysis of the new product development process of small and medium enterprises (SMEs) in China, Hong Kong and Taiwan, Industrial Marketing Management, 35: pp. 323-335.

44.Strauss, A. L., \& Corbin, J. 1998. Basics of qualitative research : techniques and procedures for developing grounded theory (2nd ed.). Thousand Oaks: Sage.

45.Tan, J., 2001. Innovation and risk-taking in a transitional economy: A comparative study of Chinese managers and entrepreneurs. Journal of Business Venturing 16 (4): 359-376.

46.Tan, K. H., Zhan, Y. Zhu., Ji, G., Ye, F. \& Chang, C. 2015. Harvesting big data to enhance supply chain innovation capabilities: An analytic infrastructure based on deduction graph. International Journal of Production Economics. 165: pp. 223-233.

47.Teece, D. J., 1986. Profiting from technological innovation: Implications for integration, collaboration, licensing and public policy. Research Policy, 15(6), pp. 285-305. 
48. Voss, C. A., N. Tsikriktsis, and M. Frohlich. 2002. Case research in operations management. International Journal of Operations and Production Management 22(2): 195-219.

49. Wang, Y. and Yao, Y., 2002. Market reforms, technological capabilities and the performance of small enterprises in China. Small Business Economics, 18: 197211.

50.Wang, L.,Yeung, J. H.Y., Zhang, M. 2011. The impact of trust and contract on innovation performance: The moderating role of environmental uncertainty. International Journal of Production Economics. 134 (1): pp.114-122.

51.Wang, Q., Zhao, X., \& Voss, C. 2016. Customer orientation and innovation: A comparative study of manufacturing and service firms. International Journal of Production Economics. 171: pp. 221-230.

52. Whittaker, D. H., Fath, B. P., \& Fiedler, A. 2016 Assembling capabilities for innovation: Evidence from New Zealand SMEs. International Small Business Journal, 34(1), 123-143.

53.World Trade Organization, 2011. World Trade Report 2011. Accessed at https://www.wto.org/english/res e/booksp e/anrep e/world trade report11 e.pdf on December 2015.

54.Xie, W. \& White, S., 2006. From imitation to creation: the critical yet uncertain transition for Chinese firms. Journal of Technology Management in China, 1 (3): pp. $229-242$.

55.Xin, J.Y. Yeung, A. C.L., \& Cheng, T.C.E. 2010. First to market: Is technological innovation in new product development profitable in health care industries? International Journal of Production Economics. 127 (1): pp. 129-135. 
56.Yang, J., Yu, G., Liu, M. Y. \& Rui, M. 2016. Improving learning alliance performance for manufacturers: Does knowledge sharing matter? International Journal of Production Economics. 171: pp. 301-308.

57. Yin, R.K. 2003. Case Study Research Design and Methods, London: Sage.

58.Zahra, S. \& George, G., 2002. Absorptive capacity: a review, re-conceptualization and extension, Academy of Management Review, 27 (2), pp. 185-203.

59.Zeng., S. X., Xie, X. M., Tam, C. M., 2010. Relationship between cooperation networks and innovation performance of SMEs, Technovation. 30: pp. 181-194.

60.Zhang, C. \& Dhaliwal, Jasbir. 2009. An investigation of resource-based and institutional theoretic factors in technology adoption for operations and supply chain management. International Journal of Production Economics. 120 (1): pp.252-269.

61.Zhang, M., Zhao, X., Voss, C., \& Zhu, G. 2016. Innovating through services, cocreation and supplier integration: Cases from China. International Journal of Production Economics. 171: pp. 289-300.

62.Zhou, Kevin Zheng. 2006. "Innovation, imitation, and new product performance: The case of China." Industrial Marketing Management 35.3: 394-402.

63.Zhu, Y., Wittmann, X., Peng, M. W., 2012, Institution-based barriers to innovation in SMEs in China, Asia Pacific Journal of Management, 29 (4), pp. 1131-1142. 